\title{
The ecological approach to the city-planning in modern megalopolises
}

\author{
Dmitry Radushinsky ${ }^{1, *}$, Thi Nhan Nguyen $^{2}$, Van Loc Nguyen $^{3}$, Marina Gubankova ${ }^{4}$, Thi \\ Mai Huong Doan ${ }^{5}$ and Alina Fatkullina ${ }^{6,7}$ \\ ${ }^{1}$ Institute for Entrepreneurship Problems LLC, 12-th line of Vassylievsky Island, 11A, 192241, Saint \\ Petersburg \\ ${ }^{2}$ Sao Do University, Số 24, phố Thái Học 2, phường Sao Đỏ, thị xã Chí Linh Hải Dương, Việt Nam \\ ${ }^{3}$ Saint Petersburg campus of the Higher School of Economics, 123, Naberezhnya Kanala Griboedova, \\ 190068 , St. Petersburg, Russia \\ ${ }^{4}$ Ural State University of Architecture and Art, 23, K. Liebknecht str., 620075, Ekaterinburg, Russia \\ ${ }^{5}$ University of Labor and Social affairs, 1018, Tô Ký, Tân Chánh Hiệp, Quận 12, Hồ Chí Min, Việt \\ Nam \\ ${ }^{6}$ Moscow State University of Civil Engineering, 26, Yaroslavskoye Shosse, 129337, Moscow, Russia \\ ${ }^{7}$ Moscow architectural institute, 11/4, Rozhdestvenka Street, 107031, Moscow, Russia
}

\begin{abstract}
The paper discusses the main stages of development and the fundamental structure of modern green roofs, the advantages and limitations of creating green roofs, features of creating green roofs in Vietnam and other countries of the Asia-Pacific Region, features of the concept of "exploited roofing" in Russia. The authors assessed the degree of greening of roofs in the center (city) of a number of major megacities of the world in 2015-2018, the level of greening of roofs in St. Petersburg, qualitative research and classification of projects for creating green roofs for various purposes and scale. The following key parameters were established, which determined the differences in the implementation of various types of projects for creating green roofs for various purposes and scale (area): the main categories of users / visitors, the main features of various types of projects, their environmental and innovative characteristics, the range of budget values and deadlines for completed projects. The branded names of the implemented roof gardening projects in St. Petersburg are given.
\end{abstract}

\section{Introduction}

At present, the arrangement of green roofs in the construction and renovation of buildings is becoming increasingly popular, becoming one of the most dynamically developing areas of landscape architecture. The shortage of land in many large cities, the lack of parks and green areas, a number of other unfavorable factors of the urban environment feed earlier "exclusive" architectural ideas and expand the spread of the approach to the rational use of the roofs of buildings and structures with the creation of architectural landscape objects based on the use of green spaces and small "park" architectural and design forms.

\footnotetext{
*Corresponding author: doptaganka@yandex.ru
} 
The main reason for interest in the "green" urban infrastructure in the world is the desire to make the city a more favorable place to live. Research, historical evidence and direct experience clearly demonstrate the important role of green infrastructure in improving urban living conditions. A well-designed, integrated green infrastructure improves living conditions, attracts professionals (the "creative class") to permanent residences and tourists to cities, and thus contributes to business development, increases property values, positively affects the decrease in crime and leads to greater social cohesion. "The better the place, the better the people are in it".

Numerous studies of green roofs carried out in Germany, Canada, Switzerland, Japan, the USA, and the UK in a number of APR countries since the 1980s have made it possible to optimize their designs and technologies that are used in many other countries, including Vietnam, Russia and others. countries (not excluding the introduction of valuable adjustments by local architects, designers, urbanists and other professionals involved in the development of urban areas). Nevertheless, scientific research on the organizational problems of arranging green roofs in the construction and reconstruction of residential buildings, taking into account the current limitations and conditions for Russia and Vietnam, is currently not enough.

The purpose of this study is to analyze a number of topical organizational and regulatory problems of implementing green roof projects, in particular those of intensive type, in the architecture of residential quarters and buildings in St. Petersburg and Hanoi, developing proposals for expanding the possibilities for creating green roofs as part of an environmental approach to architecture and urbanism.

\section{Materials and Methods}

A qualitative study was carried out, the main presupposition for which the authors consider the opportunity to analyze and identify the main features of green roof construction approaches in such specific megalopolises as Saint-Petersburg (Russia) and Hanoi (Vietnam). This paper considers only residential buildings (apartment buildings - MKD, by definition of Russian legislation), various heights - both low-rise (up to 5 floors), medium height (6-15 floors), and high-rise residential buildings (16-40 floors and more). To analyze the driving factors and problems of greening roofs, their possible solutions, which would allow expanding the use of this ecological approach in urbanistics, qualitative methods of analytical research are applied. In assessing the economic feasibility of the reconstruction of roofs using green spaces, an empirical approach was applied based on the information available to the authors on individual roof landscaping projects in St. Petersburg and Hanoi. The paper considers the positive factors of the influence of green roofs on the urban environment, the peculiarities of their maintenance and financial constraints arising from the technological requirements for the construction of green roofs.

\subsection{The main stages of development and the fundamental structure of modern green roofs}

In Europe, the mass construction of gardens on the roofs of houses began in the middle of the XIX century. This was facilitated by the emergence of new building materials. In 1867, the model of a garden created on the roof of the house of the famous German inventor and builder Karl Rabitz, presented at the World Exhibition in Paris, became a sensation. Large size construction of flat green roofs took at the end of the XIX century. and at the beginning of the XX century. in connection with the emergence of new roofing structures in the form of reinforced concrete, thanks to well-known projects, as well as the theoretical works of the most prominent architects and city planners, among whom were the Frenchman Le Corbusier 
and the American F. L. Wright. Le Corbusier made "roof-gardens" a necessary part of the architecture, developing and implementing a large number of projects using green roofs in use, ranging from small villas to large residential complexes, including a grandiose ensemble of gardens on the roofs of administrative buildings in the Indian city of Chandigarh.

Simultaneously with Le Corbusier, similar projects in many countries began to be implemented by other architects of the "new wave". For example, the Perret brothers built a profitable house in Paris in 1903 with roofs, gardens and terraces, Walter Gropius built a office building in Cologne with a restaurant on a green roof, and in America at the same time Frank Lloyd Wright designed a large restaurant in Chicago with operated green roofs [1,2]. Architect Ralph Hancock in the 1930s in London, on the roof of the six-storey building of the department store, created a garden complex called "Derry and Toms". On the roof of this building, there are still three thematic gardens: Spanish - in the Moorish style, historic Victorian - in the style of the Tudor era and landscape (English), where more than 100 species of trees are represented.

In Russia, the construction of buildings with a flat roof began in 1908, when a garden with a fountain and a rose garden appeared on the roof of the Merchant Club on Malaya Dmitrovka (now the building of the theater Lenkom). The first Moscow "skyscraper", a tenstory residential building in Bolshoy Gnezdnikovsky Lane, built by architect E. R. Nirnsee, was not left without attention. A special pavilion was set up on the flat roof of this house, surrounded by a large number of plants. Actively green roofs were created in the $20 \mathrm{~s}$ of the 20th century in the USSR, thanks to the constructivist architects G. Barkhin, I. Leonidov, the Vesnin brothers, and some others who "promoted" the construction of buildings with a flat roof. At the same time several buildings were built, on the roofs of which special observation platforms with gardens and even children's playgrounds were equipped. The Second World War introduced its own adjustments to the development of European and Soviet architecture, the design of houses with roof gardens stopped for many years. It resumed only by the end of the 20th century, and by now is once again one of the important trends in urban ecological architecture [3].

At present, green roofs have received wide international recognition, and their creation, albeit on different scales, is carried out in almost all regions of the world (see Table 1).

Table 1. Estimation of the degree of landscaping of roofs in the center (City) of a number of large megacities of the world in 2015-2018.

\begin{tabular}{|c|c|c|c|}
\hline Megalopolis & $\begin{array}{c}\text { Greening } \\
\text { rate* }\end{array}$ & Megalopolis & Greening rate* \\
\hline Oslo, Norway & $30 \%$ & Macau, China & $4,0 \%$ \\
\hline Lausanne, Switzerland & $25 \%$ & Singapore, Singapore & $4,0 \%$ \\
\hline Munich, Germany & $12 \%$ & Shenzhen, China & $3,5 \%$ \\
\hline Berlin, Germany & $8 \%$ & Shanghai and Beijing, China & $2,5 \%$ \\
\hline Osaka, Japan & $5 \%$ & Saigon, Vietnam & $2-2,5 \%$ \\
\hline Tokyo, Japan & $4,5 \%$ & Hanoi, Vietnam & $1,5 \%$ \\
\hline $\begin{array}{c}\text { New York and San } \\
\text { Diego, USA }\end{array}$ & $4,0 \%$ & Moscow, Russia & $0,4 \%$ \\
\hline London, United Kingdom & $4,0 \%$ & St. Petersburg, Russia & $0,2-0,25 \%$ \\
\hline
\end{tabular}

*Note: the table was compiled by the authors on the materials of the open press.

As follows from table 1, the trend of green roofs has received the greatest spread in the cities of such countries of Northern and Central Europe as Norway, Switzerland, Germany, and the United Kingdom. In Norway, $90 \%$ of roofs have been transferred to the category of exploited, of which a significant part is green. In the cities of Switzerland, "green" in 2016 were on average up to $25 \%$ of roofs. Currently, in Germany, when designing new buildings of a certain height in a number of urban areas, landscaping the roof is a prerequisite, and for lack of landscaping - fined. In London, in the years 2012-2017 more than 100 thousand 
square meters are planted. m. roofs. In Japan and China, they also systematically approach the greening of roofs in the center of megalopolises. In particular, in Japan it is recommended to place lawns, flower gardens and trees on all the roofs of new buildings and structures of more than 100 square meters.

Note that in less economically developed countries, the trend of greening roofs is realized, but with its own characteristics. For example, in Egypt, hydroponic technology is used to grow plants, vegetables and fruits on the roofs of buildings. This technology is cheap enough: plants are grown on wooden tables, and there is no ground directly on the roof, which means that there is no need to use insulating membranes and coatings, additional drains and other expensive roof structures (see below) [4]. However, this approach is relevant only in the southern countries with a favorable climate - a small amount of precipitation and a high level of insolation.

Currently, in Germany, where $10 \%$ of all roofs are already greened, and in several other European countries, including Austria, Italy, the Netherlands, Norway, Sweden, Switzerland and the UK, there are associations actively promoting the idea of greening roofs, conferences are being held as well as related architectural awards. In Canada and the United States, "green roofs" are also becoming popular, although their number is not as large as in Europe. Green roofs are especially popular in New York and San Diego, as well as in Canadian Ottawa [5].

The modern green roof is a layer of waterproofing, drainage material and soil planted with vegetation. Such a roof behaves like a sponge, absorbing and holding rainfall falling on it, which significantly reduces the amount of runoff from the roof and its peak flow rate and reduces the storm load on sewer systems. In climatic conditions characteristic of most cities, green roofing is an expensive construction, and for this reason high requirements for reliability and durability are imposed on the materials used in its composition. Structurally, the following layers of the roofing "pie" can be distinguished: a layer of green plantings (grass, bushes, trees); multi-layered soil; filters, separating layers; drainage, water disposal system (additional in relation to the existing or "standard" gutters); rainwater storage tanks; separation layer to protect against plant roots; heat insulation; waterproofing membrane.

In order to increase the energy efficiency of houses on roofs with landscaping, solar panels and thermal collectors can also be installed, which makes this project even more "green", but also significantly increases its cost.

\subsection{Benefits of green roofs.}

Arranging green roofs creates new energy and water saving opportunities for buildings, helps manage stormwater runoff, improves their quality, reduces air pollution and reduces the effect of urban heat island. For tenants, green roofs have an aesthetic appeal, create a new habitat for many species of plants, insects and birds and an additional factor of attractiveness when choosing housing. Greening roofs imitates the natural environment, increasing the amount of greenery that creates shade and evaporates moisture, and with sufficient investments protects the roof itself from adverse weather effects, prolonging its life cycle. In summer, it contributes to cooling the roof and reducing the air temperature both inside and outside buildings, and in winter it provides additional thermal insulation, reducing the need for energy for air conditioning and space heating. Green roofs can also provide additional protection against city noise.

The vegetation on the roof also improves air quality, producing additional oxygen in the photosynthesis process and binding carbon dioxide, and also regulates air humidity and has the ability to adsorb dust and other atmospheric pollutants. Thus, the arrangement of green roofs in the construction and renovation of buildings can significantly improve the living conditions and livelihoods of people in cities, helping to solve not only environmental, but also social problems. 
There are two types of green roofs: extensive and intensive. Extensive green roof, which does not require special care, contains over waterproofing drainage and shallow soil with grass and low-growing plants that can grow in almost alpine conditions, exposed to the sun and wind, practically does not require people to stay on the roof to care for it. Intense green roofs, resembling a small park, are more complex and require more maintenance. They have a deeper layer of soil (usually over $30 \mathrm{~cm}$ ) and a more diverse composition of plants, including trees and shrubs.

Both types of modern green roofs are complex, well-designed and carefully calculated roofing systems, the cost of which, taking into account their life cycle - when selecting adequate materials and timely designing - only slightly exceeds the cost of the usual highquality non-green roof. Intensive green roofs are more expensive than extensive ones, since they create a significantly greater load on the supporting structures (up to $900 \mathrm{~kg}$ per sq. M.), They require greater mechanical support and subsequent maintenance.

Roof area in cities is a significant part of the waterproof surfaces, which create problems such as the effect of the heat island and an increase in the volume of storm drains. In addition, smog caps, the activation of pathogens of various diseases, the concentration of a significant amount of harmful substances are relevant in the cities. The effect of the heat island in cities arises due to the fact that a huge number of cars "throws" exhaust gases into the air. This and a number of other sources of urban heat raises the temperature by 5-7 degrees above the temperature in the suburbs [6].

The urban effect of the heat island is due to the presence of a larger amount of heatabsorbing materials, such as asphalt, covering the soil in all urban areas. These materials absorb heat rather than reflect, as does vegetation cover. As a result, urban areas retain heat longer and the ambient temperature there is higher than in rural areas. If at the same time $20 \%$ of the roofs in the city are "green", then they contribute to improving air quality and reducing the total heat in the city by about three degrees, which can significantly reduce the cost of cooling rooms and air conditioning in the summer period [7].

Other negative effects of the urban effect of the heat island are increased energy demand as a result of rising temperatures, smog formation, increased ozone production, heat-related diseases, and emissions of carbon dioxide and other pollutants due to increased energy production [8]. Field studies of green roofs in Ottawa, Canada, showed that while the temperature on an ordinary roof reached $55^{\circ} \mathrm{C}$, the typical extensive green roof maintained a temperature of about $21^{\circ} \mathrm{C}$, the average temperature fluctuations on an ordinary roof during the spring and summer months were $45^{\circ} \mathrm{C}$, and on an equivalent green roof just $6^{\circ} \mathrm{C}$. [9] From this, it was concluded that green roofs can reduce the urban effect of a heat island if they are widespread throughout the city.

Green roofs have significant advantages in reducing energy consumption: a layer of soil and plants on the roof provide an additional insulating layer to the insulation already existing in the roof structure. This extra layer of insulation helps reduce the heating and cooling requirements of the building and therefore saves energy. Researchers presented a number of evidence of the benefits of green roofs - measurements and estimates were made regarding the amount of reduction in energy use that provides additional insulation provided by green roofs [10].

Greening roofs also solves the problem of reducing noise in the range from 2 to 10 decibels [11]. Other (ecological) benefits of green roofs include the following: the vegetative layer retains about $20 \%$ of dust and harmful substances contained in the air; the absorptive capacity of green roofs retain moisture up to $70 \%$ of rainwater falling on it as a result of precipitation; evaporation of rainwater helps to preserve the natural humidity of the air; green roofs are a favorable environment for plants, birds, insects [12].

\subsection{Restrictions when creating green roofs.}


The main restrictions on creating green roofs are their high investment value due to construction technologies, as well as a number of legislative restrictions related to the concept of "exploited roofing", operating both in Russia and in other countries.

Any green roof implies an increase in the load on the supporting structures - from 50 to $250 \mathrm{~kg}$ per square meter. $\mathrm{m}$ at the device of the extensive roof and up to $900 \mathrm{~kg}$ per square. $\mathrm{m}$. in the framework of intensive green roofing technology. A layer of ordinary soil, only 5 centimeters thick, and an area of 1 square meter can weigh up to 100 kilograms, and the soil is just one of the layers of the green roof. The soil layer for plants should be $30-40 \mathrm{~cm}$, to create a lawn $-15 \mathrm{~cm}$. Planting low-growing trees and shrubs increases the soil layer and increases the weight of the green roof to 700 kilograms per square meter. m., planting fruit trees can increase the load up to $900 \mathrm{~kg}$ per square meter. In winter, in addition, snow will accumulate on the green roof, even on an extensive roof and placed under a certain slope, and the roof load may increase by another 400 kilograms per square meter [13].

Ideally, the decision to create a green roof should be taken at the design stage of a house, when it is possible to calculate and plan future loads and create suitable conditions for plant growth. The green roof can be laid on overlappings of various materials - wooden (in this case usually, lightweight versions of gardening systems are planned), reinforced concrete slabs and metal frame and sheets. The main difficulties in creating roof gardens are the destructive force of the root system and wind loads, so the design of the roof garden is quite complex. As a rule, it has several insulating layers, additional wind-protective devices and a special irrigation system [14].

Technologies of arrangement of "green roofs" include the whole complex of construction works. This is a solution to the issues of waterproofing, the device drainage layer with the necessary filtration. Insulation of the green roof is extremely necessary in almost all regions of Russia, with the possible exception of the most southern ones. In contrast to Russia, in Vietnam more favorable climatic conditions suggest only some additional warming in the northern regions of the country, including the city of Hanoi [15].

The condition for the use of thermal insulation is the average winter air temperature, and if it falls below $-1^{\circ} \mathrm{C}$, the roof should be insulated. At present, synthetic materials are used for this: cellular and lightweight concretes and Foamglas foam glass. Fibrolit, expanded polystyrene and plates - cork and from wood wool on mineral binder are also used. The plant layer, which in the past served as a heater in wooden buildings, now, in high-rise concrete buildings, is not suitable for this role: when the substrate is wetted even by only $30 \%$, it in 36 largely loses its insulating properties. And long-term exposure to "stagnant" water in the drainage layer and in water devices can cause the coating to lose its insulating properties altogether [16].

\subsection{Features of creating green roofs in Vietnam and other countries of the Asia- Pacific region.}

In the cities of the Socialist Republic of Vietnam (Vietnam) live about $60 \%$ of the population in conditions of high density. In particular, the city of Saigon in Vietnam has the highest population density compared to other cities in the world. The historical features of the development of the country are such that during the hostilities in 1968-1972. in the country, the area of natural forests has decreased from $45 \%$ of the country's territory to $20 \%$, that is, more than doubled [17]. In addition, during the development of the "predatory stage" of capitalism, as a result of massive logging by private timber harvesters, forest reserves for the years $1988-1993$ were reduced by 11.4 million hectares, or by $60 \%$. In this regard, in the 2000 s, the leadership of the country's industry firmly adheres to the policy of increasing the area of forests in rural and suburban areas and green spaces within cities [18]. Greening the facades of buildings and roofs of residential buildings is a highly relevant, albeit expensive, 
technology for implementing greening programs in major cities of the country, including Hanoi. In recent decades, in rapidly expanding Vietnamese cities, a large crowd of people and closely spaced monotype houses create a gray and tiring atmosphere that local people try to dilute with plants and flowers in pots, exposing them to balconies, loggias and window sills. Based on this "popular" idea of revitalizing the urban landscape, some ecological concepts of Vietnamese architects appeared to create unique projects called Stacking Green, which means a garden house, in which the main idea is to use landscaping as an element of facades, Stone House, Residential Hill and others.

Above many conceptual projects of green houses and roof gardening were the specialists of the Vo Trong Nghia Architects architectural bureau (votrongnghia.com). In particular, for Saigon, this bureau has developed a "green" eco-quarter consisting of 1-3 storey houses lined with wood or synthetic materials resembling lumber. On the roof of each house there are terraces with lawns, flower beds, and sometimes trees, for residents to rest. Given the high probability of strong winds and storms, even on the roofs of low-rise residential buildings in Vietnam, it is not recommended to plant tall trees. According to estimates, about $2-2.5 \%$ of roofs and facades in Saigon and about 1.5\% in Hanoi are currently "green" (table 1). Thus, the process of landscaping roofs in the largest cities of Vietnam has been launched, but requires further development.

In Japan, the problems of lack of air and greenery in the cities, characteristic of Vietnam today, have been actively addressed since the 1990s. Thus, gardens on the roofs of railway stations throughout the country are annually rented out plots of three square meters in size consumers are mostly retirees, many of whom use this space for gardens. The most landscaped are the roofs in the central areas of the cities of Osaka and Tokyo, where, according to an estimate, their area is $4.5-5 \%$ of the total area of the roofs. In other rapidly developing cities of the Asia-Pacific region, a similar picture is observed. In such cities of Greater China as Macau, Singapore, and Shenzen, the percentage of greening of roofs is approaching that of some European cities, such as London. In Shanghai and Beijing, this percentage is somewhat lower, but the works are in full swing. It is estimated that by 2025 , 400 million more people will live in Chinese cities, making up a total of about 900 million people out of the 1,400 million people in the country.

As part of the rapid urbanization processes and associated air pollution problems, urbanists in China, like in Vietnam, are trying to implement the concept of a "garden city". The "garden city" projects with gardens and orchards smashed on the roofs (which have already been implemented in large Japanese cities) envisage not only a substantial increase in the level of providing people with fresh agricultural products, but also additional jobs for farmers moving from rural areas, which relevant to the "instant urbanization" process that has taken place in China in recent decades. Urban agricultural land, broken on the roofs, can also be beneficial in the framework of the organization of agro-tourism or special courses on the education of young people and all willing citizens of the basics of agriculture.

\subsection{Features of the concept of "exploited roof" in Russia, the roofs greening rate in St. Petersburg.}

In Russia, "roof and vertical gardening" is governed by clauses 2.2.10 - 2.2.24 "Guidelines for the development of norms and rules for landscaping municipalities", approved by order of the Ministry of Regional Development of the Russian Federation No. 613 of December 27, 2011. [19] The roofs of the new elite, business-class residential houses, and, less often, the comfort class, are being actively planted. The roofs of houses of the most mass economy class are planted very rarely due to an increase in the cost of construction and maintenance, which can "scare away" potential apartment buyers who are looking for cheap housing. 
The issues of roof gardening, building private and public swimming pools, botanical gardens and other opportunities to use the roof in their own interests in already built houses (historical, Soviet developments, buildings of 1990-2010) most often arise from residents of the upper floors of apartment buildings (hereafter MKD). One or another variant of the actual operation of the roof without appropriate approvals is interpreted by the State Housing Inspection as "exploitation at the expense of neighbors ..., which in fact is a self-capture of the common property of the owners, which not only infringes the interests of other residents, but also leads to the destruction of the house's structures" [20]. If at least one link in the chain of legalization of a "personal" roof is violated, the owner will be obliged to demolish any building at his own expense (and in the case of his prolonged absence, the management company is obliged to do this, which then through the court will recover all costs from the culprit). In addition, the local authorities illegally exploiting the roof will be fined for unauthorized seizure and damage to common property, "inflicted" during the construction process.

What are the legal ways to turn the roof into a holiday destination in Russia? Potentially, if you want a separate initiative occupant (residents) on the roof of an apartment building, it is possible to create a green roof, break a flower garden, garden, and build a pool, create a gym, and even open a catering establishment (cafe, restaurant, etc.). However, the roof must first be transferred to the category of exploited, that is, to formalize the opportunity to use the roof, initially on equal terms for all residents of this MCD. Until this has been done, the right to enter the roof according to the Resolution of the RF Gosstroy of September 27, 2003 No. 170 "On Approval of the Rules and Standards for the Technical Operation of the Housing Fund" has only employees of organizations (management companies) and organizations whose property is installed at the top (for example, cellular companies, television). All exits to the roof must be locked, the keys of which are in the hands of the responsible persons of service organizations.

In order to legalize any roof maintenance project, it is necessary to convene a general meeting of tenants on its transfer to the ownership of the house and subsequent reconstruction. All proprietors of apartments must unanimously vote in favor, since according to Art. 36 LCD RF and Art. 290 of the Civil Code of the Russian Federation, all tenants of the house have the right to use the roof areas on a par with the premises of the building that are in their common property (porches, staircases, elevators). The protocol, which reflects the absolute consent of all neighbors, is submitted to Rosreestr, where the roof is recognized as the property of the house. At the next stage, a repeated meeting of residents is held, at which it is decided how the roof will be operated. When at least $2 / 3$ of the owners (participants) vote for one of the options for using the roof, a report is drawn up reflecting the decision of the meeting for the housing design institute, where they will prepare a reconstruction project. Next, the finished project must be coordinated with representatives of the state construction supervision and representatives of the local authorities of the municipality (district) on whose territory the MKD is located. After that, you can begin to work on the reconstruction.

Translating the roof into the category of exploited may be of interest to residents in that it provides opportunities to improve the quality of life in the house, increase the cost per square meter in it (according to estimates by $8-20 \%$, depending on whether the roof is in common ownership or part of the roof becomes private property of residents upper floors), to diversify the leisure of children and adults. However, such a translation may frighten off by the presence of uncontrolled residents of new visitors, possible noise. Many conservative tenants, moreover, are often not satisfied with the initiatives of individual residents of the upper floors, they vote "against", which "puts a cross" on some possibilities of creating exploited roofs. Under the conditions of dacha plots, which are available to many citizens in Russia (up to $60 \%$ of the population use suburban real estate in addition to the main place of 
residence), as well as the not so favorable climate, there are no serious incentives for planting in a non-single place of residence in the form of a roof of MKD - in contrast to the middle class of other countries. A number of citizens in Russia, moreover, realize the instinct of "caring for the territory" during the summer period not using roofs of houses, as in Vietnam, Japan, China and other countries, but using the available local area beneath the houses, breaking up small flower gardens, orchards, gardens there .

The greatest scope for the implementation of projects of roofs in use in Russia, including in the form of landscaping, is usually among residents of new buildings. The buildings of the old foundation opposite the roof are often pitched - they cannot be transferred to the category of exploited [21-23]. For the arrangement of green roofs on high-rise residential and public buildings, in addition, there are special restrictions that comply with the rules and standards of high operation - more than $30 \mathrm{~m}$ - and high-rise - over $100 \mathrm{~m}$ - buildings and structures [24].

The level of greening of roofs in St. Petersburg compared to other cities of the world is low, and is no more than $0.2-0.25 \%$ of the total area of roofs in the city center (without suburbs). Mostly green roof projects are implemented during the construction of new homes of the elite and business class, less often are projects initiated by private and public management companies during the reconstruction of the $\mathrm{MKD}$, individual projects of roof reconstruction are implemented on the initiative of residents (tenants).

\section{Results}

According to a study of a complex of projects for creating green roofs of various purposes and scale, a number of conclusions can be made, which are presented in Table 2.

Table 2. The main results of a qualitative study of a complex of projects for creating green roofs for various purposes and scale.

\begin{tabular}{|c|c|c|c|c|c|}
\hline $\begin{array}{l}\text { Type of the } \\
\text { project of } \\
\text { creating a } \\
\text { "green" roof }\end{array}$ & $\begin{array}{l}\text { S, } \\
\text { sq. } \\
\text { mete } \\
\text { rs }\end{array}$ & $\begin{array}{l}\text { Main } \\
\text { categories } \\
\text { of users / } \\
\text { visitors }\end{array}$ & $\begin{array}{c}\text { Main features of the project, its } \\
\text { environmental and innovative } \\
\text { characteristics }\end{array}$ & $\begin{array}{l}\text { Budget, } \\
\text { timeline }\end{array}$ & $\begin{array}{l}\text { Examples of } \\
\text { implementation }\end{array}$ \\
\hline 1 & 2 & 3 & 4 & 5 & 6 \\
\hline $\begin{array}{l}\text { I. Personal lawn } \\
\text { garden / garden / } \\
\text { penthouse } \\
\text { owner or } \\
\text { allocated rights } \\
\text { to the green roof } \\
\text { plot }\end{array}$ & $\begin{array}{c}3- \\
300\end{array}$ & $\begin{array}{l}\text { Individual- } \\
\text { owner - } \\
\text { from full- } \\
\text { sized to } \\
\text { retire-es } \\
\text { and middle- } \\
\text { class } \\
\text { members, - } \\
\text { his family } \\
\text { members }\end{array}$ & $\begin{array}{l}\text { 1. Intensive green roof requiring } \\
\text { care (this is often the "interest" } \\
\text { for pensioners in large cities of } \\
\text { such countries with a lack of } \\
\text { "living space" like Japan, } \\
\text { Vietnam, densely populated } \\
\text { areas of China and other } \\
\text { countries of the Asia-Pacific } \\
\text { Region). } \\
\text { 2. A green roof can only be a part } \\
\text { of the entire roof of a building } \\
\text { and provide additional benefits } \\
\text { only to its actual owner } \\
\text { (operator). }\end{array}$ & $\begin{array}{l}0.2-10 \\
\text { million } \\
\text { rubles. } \\
\text { and } \\
\text { more; 1- } \\
5 \text { months } \\
\text { (excludi } \\
\text { ng } \\
\text { reconcili } \\
\text { ation } \\
\text { time) }\end{array}$ & $\begin{array}{l}\text { Allocated areas of } \\
\text { roofs in Japan, the } \\
\text { roofs are in the } \\
\text { personal property } \\
\text { of residents of the } \\
\text { upper floors in } \\
\text { residences in cities } \\
\text { around the world }\end{array}$ \\
\hline $\begin{array}{l}\text { II. Different } \\
\text { directions of } \\
\text { creating } \\
\text { exploited roofs, } \\
\text { in which access } \\
\text { to an object / } \\
\text { establishment } \\
\text { created on the } \\
\text { roof is allowed } \\
\text { to an unlimited }\end{array}$ & $\begin{array}{c}50- \\
500\end{array}$ & $\begin{array}{l}\text { Vacationers } \\
\text { and tourists, } \\
\text { visitors to } \\
\text { restaurants, } \\
\text { art } \\
\text { exhibitio- } \\
\text { ns, musical } \\
\text { events, } \\
\text { connoisseur } \\
\text { s of cinema, }\end{array}$ & $\begin{array}{l}\text { 1. The object is created for } \\
\text { commercial use, and the green } \\
\text { roof or its elements are an } \\
\text { integral part of the design, attract } \\
\text { visitors. } \\
\text { 2. The green roof is not the main } \\
\text { attraction for the main categories } \\
\text { of visitors, but its presence } \\
\text { necessitates the need for } \\
\text { appropriate engineering and }\end{array}$ & $\begin{array}{l}5 \quad-50 \\
\text { million } \\
\text { rubles. } \\
\text { and } \\
\text { more; 2- } \\
7 \text { months } \\
\text { (excludi } \\
\text { ng } \\
\text { reconcili }\end{array}$ & 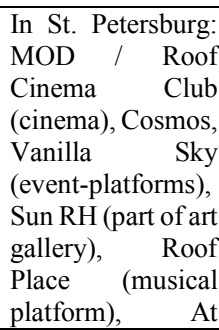 \\
\hline
\end{tabular}




\begin{tabular}{|c|c|c|c|c|c|}
\hline $\begin{array}{l}\text { Type of the } \\
\text { project of } \\
\text { creating a } \\
\text { "green" roof }\end{array}$ & $\begin{array}{l}\text { S, } \\
\text { sq. } \\
\text { mete } \\
\text { rs }\end{array}$ & $\begin{array}{l}\text { Main } \\
\text { categories } \\
\text { of users / } \\
\text { visitors }\end{array}$ & $\begin{array}{l}\text { Main features of the project, its } \\
\text { environmental and innovative } \\
\text { characteristics }\end{array}$ & $\begin{array}{l}\text { Budget, } \\
\text { timeline }\end{array}$ & $\begin{array}{l}\text { Examples of } \\
\text { implementation }\end{array}$ \\
\hline $\begin{array}{l}\text { circle of people, } \\
\text { but at a time } \\
\text { limited by city } \\
\text { laws } \\
\text { (regulations) }\end{array}$ & & $\begin{array}{l}\text { other } \\
\text { categories } \\
\text { of visitors } \\
\text { in } \\
\text { accordance } \\
\text { with the } \\
\text { thematic } \\
\text { purpose of } \\
\text { the object }\end{array}$ & $\begin{array}{l}\text { routine maintenance by } \\
\text { gardener's / landscape design } \\
\text { specialists. } \\
\text { 3. The object is an architecturally } \\
\text { design and cultural project, } \\
\text { which sets standards and spreads } \\
\text { the "culture" and technologies of } \\
\text { using roofs in the city, thus } \\
\text { expanding the range of } \\
\text { opportunities for visitors. }\end{array}$ & $\begin{array}{l}\text { ation } \\
\text { time) }\end{array}$ & $\begin{array}{l}\text { Height (sports and } \\
\text { sauna complex) }\end{array}$ \\
\hline $\begin{array}{l}\text { III. Creation of } \\
\text { quarters with } \\
\text { green roofs on } \\
\text { buildings and } \\
\text { facilities for } \\
\text { residential, } \\
\text { administrative, } \\
\text { industrial } \\
\text { purposes }\end{array}$ & $\begin{array}{l}500- \\
5000 \\
\text { and } \\
\text { more }\end{array}$ & $\begin{array}{l}\text { All } \\
\text { residents of } \\
\text { this quarter } \\
\text { (or a } \\
\text { separate } \\
\text { building in } \\
\text { the quarter), } \\
\text { employees } \\
\text { of an } \\
\text { institution } \\
\text { or } \\
\text { enterprise }\end{array}$ & $\begin{array}{l}\text { 1. Roofs are greened in the } \\
\text { framework of long-term projects } \\
\text { to maintain and increase energy } \\
\text { efficiency, the ecology of } \\
\text { territories, the renovation of the } \\
\text { urban environment. } \\
\text { 2. They require an integrated } \\
\text { approach, modern engineering } \\
\text { solutions, expensive equipment, } \\
\text { in the conditions of Russia - as a } \\
\text { rule, imported. } \\
\text { 3. The introduction of new and } \\
\text { promising urban development } \\
\text { technologies, which creates an } \\
\text { additional visual and } \\
\text { "kinesthetic" effect for residents } \\
\text { and visitors. }\end{array}$ & $\begin{array}{l}30-500 \\
\text { million } \\
\text { rubles. } \\
\text { and } \\
\text { more; } \\
\text { from } 6 \\
\text { months } \\
\text { (later } \\
\text { deadline } \\
\text { s for the } \\
\text { impleme } \\
\text { ntation } \\
\text { of } \\
\text { projects) }\end{array}$ & $\begin{array}{l}\text { Residential } \\
\text { quarters in St. } \\
\text { Petersburg: } \\
\text { "Light-World Mir. } \\
\text { Inside" (Sun- } \\
\text { Dunes), } \\
\text { "Privilegy" (Cross } \\
\text { Island). Blocks } \\
\text { with green roofs in } \\
\text { a number of mega- } \\
\text { policies of the } \\
\text { world }\end{array}$ \\
\hline
\end{tabular}

\section{Conclusions}

According to the data presented in Table 2, the work establishes the classification of projects for creating green roofs for various purposes and scale (area), the composition of the main categories of users / visitors, identifies the main features of various types of projects, their environmental and innovative characteristics, as well as the range of budget values and deadlines for implemented projects are given branded names of practical examples of implementation. The results of the work can be used as an analytical base by private investors, municipal and regional authorities in the preparation of plans for the strategic development of green roof projects. The information provided may be of interest to specialists of territorial divisions of urban planning and urban planning, and other interested experts. The key areas for further research are the authors consider a thorough study with the identification of features and taking into account the "best practices" in the few examples of "green" roofs in the lit. "Roofs in the framework of creating multifunctional social spaces, environmentally friendly (environmentally -" friendly ") and innovative development, construction projects, in in the framework of projects for the reconstruction of individual buildings and structures and redevelopment [23] of urban areas.

\section{References}

1. Le Corbusier, L'Atelier de la recherche patiente (Paris, 1960)

2. H. Grub, Greenery between the houses. Ideas, concepts, examples of the introduction of elements of nature into the production environment (Ipobank, Munich, 1988) 
3. E.A. Maltseva, D.A. Egorova, Synergy of Sciences 21, 478-505 (2018)

4. Y. Ampim, A. Peter, J. Sloan, R. Cabrera, D. Harp, F. Jaber, Journal of Environmental Horticulture 28(4), 136-143 (2016)

5. G. Heidarinejad, A. Esmaili, Energy Conversion and Management 106, 1418-1425 (2015)

6. G. Hopkins, C. Goodwin, Living Architecture: Green Roofs and Walls (CSIRO Collingwood, Australia, 2011)

7. T. Beatley, Green Cities of Europe: Global Lessons on Green Urbanism (Island Press, Washington DC, 2012)

8. T. Emilsson, Greening Rooftops for Sustainable Communities (Chicago, 2003)

9. E.C. Snodgrass, L. McIntyre, The Green Roof Manual: A Professional Guide to Design, Installation, and Maintenance (Timber Press, Portland, Oregon, 2010)

10. T. Osmundson, Roof Gardens: History, Design, and Construction (W.W. Norton \& Company Ltd, New York, 1999)

11. M. Semaan, A. Pearce, Procedia Engineering 145, 333-339 (2016)

12. V. Costanzo, G. Evola, L. Marletta, Energy and Buildings 114, 247-255 (2016)

13. J. Maclor, J. Lundholm, Ecological Engineering 37, 407-417 (2011)

14. Rowe, D.B., C.L. Rugh, N. VanWoert, M.A. Monterusso, D.K. Russell, Greening Rooftops for Sustainable Communities (Chicago, 2003)

15. A. Mottaeva, MATEC Web of Conference 193, 01022 (2018) doi.org/10.1051/matecconf/201819301022

16. J.T. Tourbier, The Routledge Handbook of Urban Ecology (Oxon, Routledge, 2011)

17. Vietnam: war and the environment (Green Left Weekly, Vietnam, 1993)

18. T.N. Nguyen, V.L. Nguyen, Administrative consulting 10, 253-262 (2016)

19. I. Potekhin, V. Mischenko, A. Mottaeva, A. Zheltenkov, E3S Web of Conferences 33, 03020 (2018) doi: 10.1051/e3sconf/20183303020

20. S.A. Ignatiev, D.S. Kessel, Mining Institute Notes, Series: Geoecology and life safety 220, 622-626 (2016)

21. D. Radushinsky, A. Gubankov, A. Mottaeva, E3S Web Conf. High-Rise Construction 2017 (HRC 2017) 33, 01042 (2018)

22. M. Pasetti, C. Invernizzi, P. Iora, Appl Therm Eng, 73, 1 762-772 (2014), DOI: 10.1016/j.applthermaleng.2014.08.017

23. B. Marchi, M. Pasetti, S. Zanoni. Life cycle cost analysis for BESS optimal sizing, Energy Proced, 113 127-134, (2017), DOI: 10.1016/j.egypro.2017.04.034

24. D. Radushinsky, A. Radushinskaya, I. Radikov, O. Feoktistova, A. Butyrin, MATEC Web of Conferences 35, 01043 (2018) 